\title{
GEOCHEMICAL ANALYSIS OF GROUNDWATER QUALITY IN AGBARA AND ENVIRONS
}

\author{
GBADEBO, A.M. ${ }^{1}-$ TAIWO, A.M. ${ }^{1} *-$ AYEDUN, H. $^{2}-$ ADEOLA, A.J. $^{3}$ \\ ${ }^{I}$ Department of Environmental Management and Toxicology, University of Agriculture, PMB \\ 2240 Abeokuta, Nigeria \\ ${ }^{2}$ Department of Science Laboratory Technology, Federal Polytechnic, PMB 50 Ilaro, Nigeria \\ ${ }^{3}$ Department of Geology, Crawford University, Faith City, Km 8, Atan-Lusada Road, Igbesa, \\ Ogun State, Nigeria \\ Corresponding author \\ E-mail: taiwoademat2003@yahoo.com
}

(Received $27^{\text {th }}$ December 2011; accepted $10^{\text {th }}$ February 2012)

\begin{abstract}
This study examines the geochemical compositions of groundwater from three communities viz: Agbara, Igbesa and Lusada to determine their suitability for human consumption. A total of seventeen (17) boreholes were sampled and analyzed using standard procedures. The parameters determined include: $\mathrm{pH}$, temperature, electrical conductivity (EC), redox potential (RP), biochemical oxygen demand (BOD), anions $\left(\mathrm{Cl}^{-}, \mathrm{PO}_{4}{ }^{3-}, \mathrm{NO}_{3}^{-}, \mathrm{SO}_{4}{ }^{2-}, \mathrm{HCO}_{3}^{-}\right.$and metals $\left(\mathrm{As}^{2+}, \mathrm{Ca}^{2+}, \mathrm{Mg}^{2+}, \mathrm{K}^{+}, \mathrm{Na}^{+}\right.$, $\mathrm{Mn}^{2+}$ and $\mathrm{Cd}^{2+}$ ). Results showed variations in the values of water quality parameters from one community to another. $\mathrm{pH}$ of water samples from Agbara and Igbesa were acidic (4.1 - 5.8) and generally fell below World Health Organization (WHO) limit of $6.5-8.5$ while that of Lusada was within the WHO range. Chloride, phosphate, bicarbonate and BOD values were generally high in all the three study areas greater than the acceptable limits in drinking water. Metal concentrations in all the sampled groundwater were very low while cadmium and arsenic were not detected in Igbesa and Lusada samples. Since most of the parameters with abnormal values have no (WHO) health-based guidelines, groundwater in these study areas may be suitable for direct consumption.
\end{abstract}

Keyword: groundwater resource, geochemistry, parameters, consumption, Agbara

\section{Introduction}

Groundwater exploitation - for the purpose of supplying good quality drinking water is widely practiced in many developing nations of the world. This is achieved by well sinking, which could be shallow (hand dug or tube wells), or deep as in the case of boreholes. Well sinking is not a new phenomenon but an ancient craft that had been in practice for thousands of years (Todd, 1980). It is an essential resource that supplies drinking water to a large number of people in Nigeria in the urban and rural areas. The study of geochemical compositions of groundwater is therefore, important due to the attached significance for potable water-supply. Besides, it is an alternative against the epileptic supply of pipe-borne water by the water authority. However, the quality of any groundwater resource in terms of physical, chemical and biological compositions determines its fitness for human consumption and diverse usage. These qualities, in turn, are functions of groundwater ionic species like $\mathrm{Na}^{+}, \mathrm{K}^{+}, \mathrm{Ca}^{2+}, \mathrm{Mg}^{2+}, \mathrm{HCO}_{3}^{-}, \mathrm{NO}_{3}{ }^{-}$, $\mathrm{SO}_{4}{ }^{2-}$, and $\mathrm{Cl}^{-}$(Sadashivaiah et al., 2008). Human activities such as sewage disposal, industrial waste products, agriculture are as well capable of altering groundwater quality (Adekunle et al., 2007). The influence of water ions on groundwater chemistry depends on their concentrations in the aquifer. Groundwater quality also relies on the 
compositions of water recharged into the ground, the interaction between it and media of the aquifer; the reactions that take place in the aquifer and the overlying soil (Rahaman, 1976). International standards have been set as criteria for drinking water quality by relevant bodies such as World Heath Organization (WHO), European Community, (EC) and United State Environmental Protection Agency (USEPA). The essence of this is to safeguard the public health against waterborne diseases. However, there are no water standard guidelines for drinking water in Nigeria. The defunct Federal Environmental Protection Agency, FEPA (1991) had only successfully set guidelines for effluents discharge into Nigeria's waterways, in which compliance was at the moment at zero level. It is therefore, necessary to assess the quality of some of these aquifers and compared it with the international standards. This will however, create a public awareness on the possible health risks attached to abnormal geochemical values of the groundwater especially in the study communities.

Many works have been done on the groundwater quality from the southwestern Nigeria. Adekunle et al. (2007) had analyzed groundwater quality of hand-dugs wells from Igbora in Oyo state. Results showed pollutions of wells located close to dumping sites. High water parameters such as nitrate, $\mathrm{BOD}, \mathrm{Cd}, \mathrm{Pb}$ and Coliforms were recorded higher than WHO standard indicating organic pollution. Groundwater resource from Lagos state has been studied by Yusuf (2007) and Longe and Balogun (2009). Gbadebo et al. (2010) had also observed high nitrate concentrations in groundwater aquifer from Sango and Abeokuta in Ogun state. Taiwo et al. (2011) had reported the physicochemical characteristics of groundwater quality of wells sampled in Abeokuta. The metal contents of boreholes sampled in Sango has been studied by Ayedun et al (2011), while a comprehensive geochemical analysis of groundwater aquifers in Sango had been carried out by Gbadebo and Taiwo (2011). The major concern of groundwater in southwestern Nigeria is the issue of high nitrate concentration. High nitrate concentrations in these groundwater aquifers might be connected to seepage of leachates from septic tanks, dumping sites and agricultural activities. Nitrate value greater than permissible standard in drinking water could pose a health problem to infants less than 6 months of age for blue baby syndrome (Taiwo, 2010). Faecal pollution of the groundwater in southwestern Nigeria has also been documented (Adekunle et al., 2007, Orebiyi et al., 2009).

\section{Materials and methods}

\section{Study areas}

The study areas, which include Agbara, Igbesa and Lusada is situated within longitude $3^{\circ} 04^{\prime}$ and $3^{\circ} 10^{\prime} \mathrm{E}$, and latitude $6^{\circ} 31^{\prime}$ and $6^{\circ} 34^{\prime} \mathrm{N}$ in Ado Odo/ Ota Local Government, Ogun state (Fig. 1), Nigeria. Agbara is noted for industrial activities in Ogun state while the Igbesa and Lusada are civil communities characterized by peasant farming with little or no viable industrial activities. Table 1 shows the sampling locations and their coordinates. 


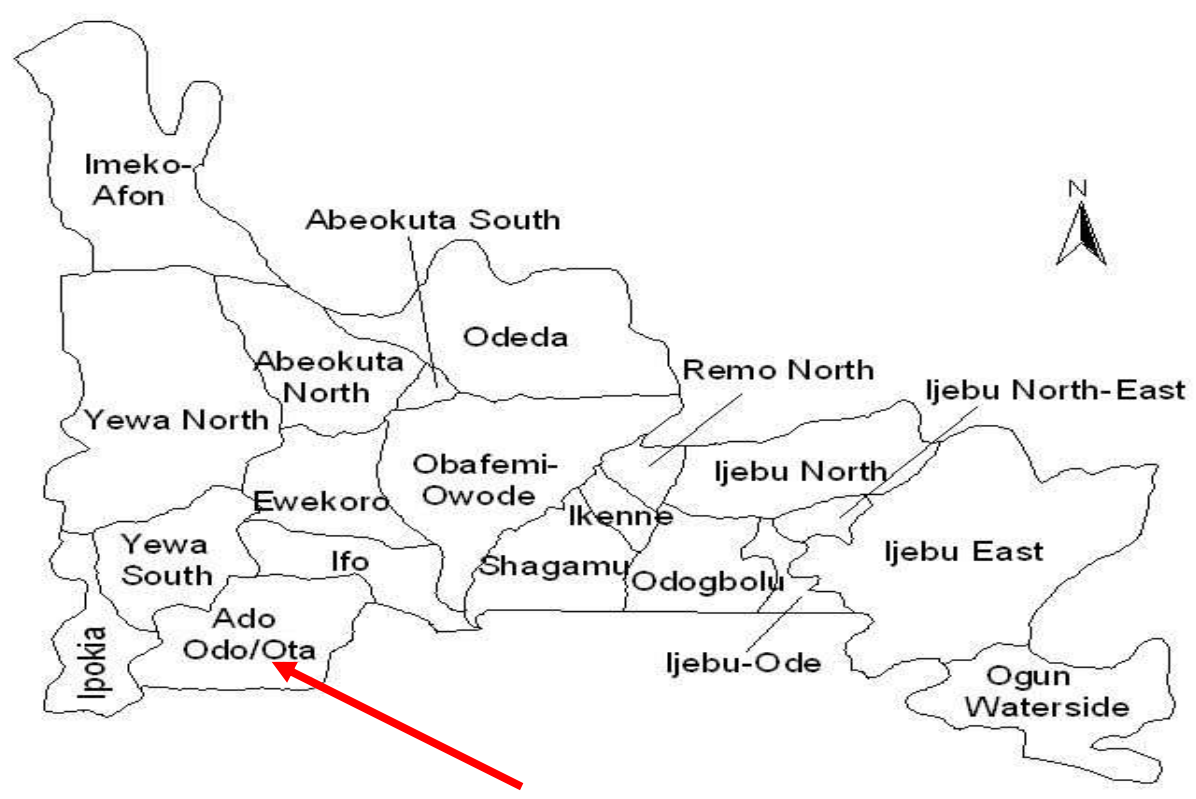

Figure 1. The map of Ogun State showing the Local Governmnet Areas (red arrow pointing to the study areas)

Table 1. Description of the groundwater locations

\begin{tabular}{c|c|c|c}
\hline $\begin{array}{c}\text { Borehole } \\
\text { Serial number }\end{array}$ & Location & $\begin{array}{c}\text { Latitude } \\
\mathbf{N}\end{array}$ & $\begin{array}{c}\text { Longitudes } \\
\mathbf{E}\end{array}$ \\
\hline 1 & Joak Block & $06^{\circ} 34^{\prime} 319^{\prime \prime}$ & $003^{\circ} 04^{\prime} 897^{\prime \prime}$ \\
2 & Omiata Block & $06^{\circ} 33^{\prime} 701^{\prime \prime}$ & $003^{\circ} 04^{\prime} 758^{\prime \prime}$ \\
3 & Car Wash & $06^{\circ} 31^{\prime} 951^{\prime \prime}$ & $003^{\circ} 04^{\prime} 537^{\prime \prime}$ \\
4 & $06^{\circ} 31^{\prime} 545^{\prime \prime}$ & $003^{\circ} 04^{\prime} 566^{\prime \prime}$ \\
5 & Dive Primary School & $06^{\circ} 31^{\prime} 431^{\prime \prime}$ & $003^{\circ} 04^{\prime} 493^{\prime \prime}$ \\
6 & Opic estate1 & $003^{\circ} 04^{\prime} 737^{\prime \prime}$ \\
7 & Baptist church & $06^{\circ} 31^{\prime} 042^{\prime \prime}$ & $003^{\circ} 04^{\prime} 769^{\prime \prime}$ \\
8 & Opic estate 2 & $06^{\circ} 31^{\prime} 090^{\prime \prime}$ & $003^{\circ} 04^{\prime} 690^{\prime \prime}$ \\
9 & Crawford University1 & $06^{\circ} 30^{\prime} 553^{\prime \prime}$ & $003^{\circ} 04^{\prime} 708^{\prime \prime}$ \\
10 & Crawford University2 & $06^{\circ} 30^{\prime} 682^{\prime \prime}$ & $003^{\circ} 04^{\prime} 605^{\prime \prime}$ \\
11 & Crawford University3 & $06^{\circ} 30^{\prime} 731^{\prime \prime}$ & $003^{\circ} 04^{\prime} 424^{\prime \prime}$ \\
12 & Ketu-Adie Owe1 & $06^{\circ} 30^{\prime} 853^{\prime \prime}$ & $003^{\circ} 04^{\prime} 164^{\prime \prime}$ \\
13 & Ketu-Adie Owe2 & $06^{\circ} 30^{\prime} 935^{\prime \prime}$ & $003^{\circ} 04^{\prime} 599^{\prime \prime}$ \\
14 & Crawform Guest house & $06^{\circ} 30^{\prime} 688^{\prime \prime}$ & $003^{\circ} 04^{\prime} 733^{\prime \prime}$ \\
15 & GRA Igbesa & $06^{\circ} 30^{\prime} 561^{\prime \prime}$ & $003^{\circ} 04^{\prime} 892^{\prime \prime}$ \\
16 & Lusada1 & $06^{\circ} 35^{\prime} 176^{\prime \prime}$ & $003^{\circ} 04^{\prime} 123^{\prime \prime}$ \\
17 & Grace court hotel & $06^{\circ} 35^{\prime} 010^{\prime \prime}$ & $003^{\circ} 04^{\prime} 055^{\prime \prime}$
\end{tabular}

\section{Geology of the study area}

The study areas (Agbara, Lusada and Igbesa) form part of Dahomey basin, a very extensive sedimentary basin on the continental margin on the Gulf of Guinea, which extends from Volta River Delta, Southeastern Ghana in the west, to the Western flank of the Niger Delta (Jones and Hockey, 1964). This Formation known as Coastal Plain Sand is made up of poorly sorted sands, which are in parts cross-bedded and shows transitional to continental characteristics like Ilaro and Abeokuta Formations. The thickness of coastal plain sand ranges from $10 \mathrm{~m}$ to $100 \mathrm{~m}$ while the age falls under Pleistocene and Oligocene (Jones and Hockey, 1964). 


\section{Methodology}

To determine the chemical constituent of the groundwater, a total of 17 borehole water samples were analyzed in this study in for physico-chemical parameters using standard procedures (APHA, 1989). The parameters evaluated were $\mathrm{pH}$, temperature, electrical conductivity (EC), redox potential (RP), biochemical oxygen demand (BOD), chloride, phosphate, nitrate, sulphate, bicarbonate and metals (arsenic, calcium, magnesium, potassium, sodium, manganese and cadmium). Parameters like $\mathrm{pH}$, temperature, EC and RP were measured in-situ using probe methods while BOD was determined by dilution method. However, chloride, sulphate and bicarbonate were determined in the laboratory by titrimetric method while phosphate and nitrate were assayed using spectrophotometric method. Analysis of metals was carried out by Atomic Absorption Spectrophotometry (AAS) except sodium and potassium which were determined by flame photometric method.

Table 2. Summary of analytical data of groundwater from Agbara

\begin{tabular}{|c|c|c|c|}
\hline Parameters & Mean \pm SD & Range & WHO (2008) \\
\hline $\begin{array}{c}\text { Temperature } \\
\left({ }^{\circ} \mathrm{C}\right)\end{array}$ & $29.2 \pm 17.2$ & $27.7-32.2$ & \\
\hline $\mathrm{pH}$ & $4.34 \pm 0.54$ & $4.10-4.81$ & $6.5-8.5$ \\
\hline $\begin{array}{l}\text { Electrical conductivity } \\
\qquad\left(\mu \mathrm{S} \mathrm{cm}^{-1}\right)\end{array}$ & $349 \pm 9.74$ & $195-721$ & \\
\hline $\begin{array}{l}\text { Redox Potential (RP) } \\
\text { (mV) }\end{array}$ & $350.4 \pm 18.51$ & $346-380$ & \\
\hline $\begin{array}{c}\text { BOD } \\
\left(\mathrm{mg} \mathrm{L}^{-1}\right)\end{array}$ & $11.14 \pm 18.51$ & $10.43-12.67$ & \\
\hline $\begin{array}{l}\text { Chloride } \\
\left(\mathrm{mg} \mathrm{L}^{-1}\right)\end{array}$ & $937.5 \pm 569.40$ & $531.5-1455.5$ & $200-300$ \\
\hline $\begin{array}{l}\text { Phosphate } \\
\left(\mathrm{mg} \mathrm{L}^{-1}\right)\end{array}$ & $7.83 \pm 0.32$ & $7.03-9.43$ & \\
\hline $\begin{array}{l}\text { Sulphate } \\
\left(\mathrm{mg} \mathrm{L}^{-1}\right)\end{array}$ & $15.7 \pm 0.89$ & $14.0-18.05$ & $<250$ \\
\hline Nitrate $\left(\mathrm{mg} \mathrm{L}^{-1}\right)$ & $0.01 \pm 0.00$ & $0.01-0.02$ & 50 \\
\hline $\begin{array}{l}\text { Bicarbonate } \\
\left(\mathrm{mg} \mathrm{L}^{-1}\right)\end{array}$ & $1804 \pm 250.24$ & $1022-2628$ & \\
\hline $\begin{array}{l}\text { Arsenic } \\
\left(\mathrm{mg} \mathrm{L}^{-1}\right)\end{array}$ & $0.01 \pm 0.00$ & $0.01-0.02$ & 0.01 \\
\hline $\begin{array}{l}\text { Calcium } \\
\left(\mathrm{mg} \mathrm{L}^{-1}\right)\end{array}$ & $15.0 \pm 0.04$ & $10.0-23.0$ & $100-200$ \\
\hline $\begin{array}{l}\text { Potassium } \\
\left(\mathrm{mg} \mathrm{L}^{-1}\right)\end{array}$ & $3.0 \pm 0.04$ & $2.0-4.0$ & \\
\hline Sodium & $15.0 \pm 0.04$ & $14.0-16.0$ & 200 \\
\hline $\begin{array}{l}\text { Magnesium } \\
\left(\mathrm{mg} \mathrm{L}^{-1}\right)\end{array}$ & $3.0 \pm 0.01$ & $2.0-13.0$ & 250 \\
\hline $\begin{array}{c}\text { Iron } \\
\left(\mathrm{mg} \mathrm{L}^{-1}\right)\end{array}$ & $0.96 \pm 0.39$ & $0.00-2.00$ & 0.30 \\
\hline $\begin{array}{l}\text { Manganese } \\
\left(\mathrm{mg} \mathrm{L}^{-1}\right)\end{array}$ & $0.01 \pm 0.05$ & $0.00-0.10$ & 0.40 \\
\hline $\begin{array}{l}\text { Cadmium } \\
\left(\mathrm{mg} \mathrm{L}^{-1}\right)\end{array}$ & ND & & 0.003 \\
\hline
\end{tabular}

SD- Standard Deviation, ND-Not Detected, BOD-Biological Oxygen Demand 


\section{Results}

Geochemical values of groundwater samples in Agbara, Igbesa and Lusada were shown in Table 2-4 respectively. Results of geochemical parameters follow similar trends in the three communities with results range: temperature $\left(27.7-33.2{ }^{\circ} \mathrm{C}\right), \mathrm{pH}$ (4.10-7.77), EC (195-721 $\left.\mu \mathrm{S} \mathrm{cm}{ }^{-1}\right)$, RP (344-390 mV), BOD (9.47-15.3 $\left.\mathrm{mg} \mathrm{L}^{-1}\right)$, chloride (531.5-3088.5 mg L $\left.\mathrm{m}^{-1}\right)$, phosphate (6.94-9.43 $\left.\mathrm{mg} \mathrm{L}^{-1}\right)$, sulphate (10.75-18.05 $\mathrm{mg} \mathrm{L}^{-1}$ ), nitrate $\left(0.01-0.02 \mathrm{mg} \mathrm{L}^{-1}\right)$, bicarbonate $\left(1022-2628 \mathrm{mg} \mathrm{L}^{-1}\right)$, As (ND-0.02 mg $\left.\mathrm{L}^{-1}\right), \mathrm{Ca}\left(2.0-120.0 \mathrm{mg} \mathrm{L}^{-1}\right), \mathrm{K}\left(1.0-20 \mathrm{mg} \mathrm{L}^{-1}\right), \mathrm{Na}\left(14.0-38.0 \mathrm{mg} \mathrm{L}^{-1}\right), \mathrm{Mg}(1.0-13.0 \mathrm{mg}$ $\left.\mathrm{L}^{-1}\right), \mathrm{Fe}\left(0.0-2.0 \mathrm{mg} \mathrm{L}^{-1}\right), \mathrm{Mn}\left(0.0-0.30 \mathrm{mg} \mathrm{L}^{-1}\right)$ and $\mathrm{Cd}\left(\mathrm{ND}-0.02 \mathrm{mg} \mathrm{L}^{-1}\right)$.

Table 3. Summary of analytical data of groundwater from Igbesa

\begin{tabular}{|c|c|c|c|}
\hline Parameters & Mean \pm SD & Range & WHO (2008) \\
\hline Temperature $\left({ }^{\circ} \mathrm{C}\right)$ & $30.32 \pm 1.72$ & $28.1-33.2$ & \\
\hline $\mathrm{pH}$ & $4.78 \pm 5.04$ & $4.28-5.84$ & $6.5-8.5$ \\
\hline $\begin{array}{l}\text { Electrical conductivity } \\
\qquad\left(\mu \mathrm{S} \mathrm{cm}^{-1}\right)\end{array}$ & $377.5 \pm 9.74$ & $345-410$ & \\
\hline $\begin{array}{l}\text { Redox Potential (RP) } \\
(\mathrm{mV})\end{array}$ & $350.86 \pm 18.51$ & $344-385$ & \\
\hline $\begin{array}{c}\mathrm{BOD} \\
\left(\mathrm{mg} \mathrm{L}^{-1}\right)\end{array}$ & $11.41 \pm 19.82$ & $9.47-15.3$ & \\
\hline $\begin{array}{l}\text { Chloride } \\
\left(\mathrm{mg} \mathrm{L}^{-1}\right)\end{array}$ & $1887.64 \pm 569.40$ & $1132-3088.5$ & $200-300$ \\
\hline $\begin{array}{l}\text { Phosphate } \\
\left(\mathrm{mg} \mathrm{L}^{-1}\right)\end{array}$ & $7.55 \pm 0.32$ & $6.94-8.05$ & \\
\hline $\begin{array}{l}\text { Sulphate } \\
\left(\mathrm{mg} \mathrm{L}^{-1}\right)\end{array}$ & $13.27 \pm 0.89$ & $11.93-14.4$ & $<250$ \\
\hline Nitrate $\left(\mathrm{mg} \mathrm{L}^{-1}\right)$ & $0.01 \pm 0.00$ & $0.01-0.02$ & 50 \\
\hline $\begin{array}{l}\text { Bicarbonate } \\
\left(\mathrm{mg} \mathrm{L}^{-1}\right)\end{array}$ & $1585.1 \pm 250.24$ & $1153-1826$ & \\
\hline $\begin{array}{l}\text { Arsenic } \\
\left(\mathrm{mg} \mathrm{L}^{-1}\right)\end{array}$ & $0.01 \pm 0.00$ & $0.01-0.02$ & 0.01 \\
\hline $\begin{array}{l}\text { Calcium } \\
\left(\mathrm{mg} \mathrm{L}^{-1}\right)\end{array}$ & $30.0 \pm 5.04$ & $20-120$ & $100-200$ \\
\hline $\begin{array}{l}\text { Potassium } \\
\left(\mathrm{mg} \mathrm{L}^{-1}\right)\end{array}$ & $3.0 \pm 1.50$ & $1.0-10.0$ & \\
\hline $\begin{array}{l}\text { Sodium } \\
\left(\mathrm{mg} \mathrm{L}^{-1}\right)\end{array}$ & $21.0 \pm 2.04$ & $15.0-26.0$ & 200 \\
\hline $\begin{array}{l}\text { Magnesium } \\
\left(\mathrm{mg} \mathrm{L}^{-1}\right)\end{array}$ & $2.0 \pm 1.01$ & $1.0-4.0$ & 250 \\
\hline $\begin{array}{c}\text { Iron } \\
\left(\mathrm{mg} \mathrm{L}^{-1}\right)\end{array}$ & $0.46 \pm 0.39$ & $0.00-1.10$ & 0.30 \\
\hline $\begin{array}{l}\text { Manganese } \\
\left(\mathrm{mg} \mathrm{L}^{-1}\right)\end{array}$ & $0.06 \pm 0.05$ & $0.00-0.20$ & 0.40 \\
\hline $\begin{array}{l}\text { Cadmium } \\
\left(\mathrm{mg} \mathrm{L}^{-1}\right)\end{array}$ & $0.01 \pm 0.02$ & $0.0-0.02$ & 0.003 \\
\hline
\end{tabular}

SD- Standard Deviation, ND-Not Detected, BOD-Biological Oxygen Demand 
Table 4. Summary of analytical data groundwater from Lusada

\begin{tabular}{|c|c|c|c|}
\hline Parameters & Mean \pm SD & Range & WHO (2008) \\
\hline $\begin{array}{l}\text { Temperature } \\
\left({ }^{\circ} \mathrm{C}\right)\end{array}$ & $29.3 \pm 0.33$ & $28.9-29.4$ & \\
\hline $\mathrm{pH}$ & $6.74 \pm 0.10$ & $6.52-7.77$ & $6.5-8.5$ \\
\hline $\begin{array}{l}\text { Electrical conductivity } \\
\qquad\left(\mu \mathrm{S} \mathrm{cm}^{-1}\right)\end{array}$ & $253.3 \pm 5.19$ & $308-417$ & \\
\hline $\begin{array}{l}\text { Redox Potential (RP) } \\
\qquad(\mathrm{mV})\end{array}$ & $360.67 \pm 5.44$ & $359-390$ & \\
\hline $\begin{array}{c}\mathrm{BOD} \\
\left(\mathrm{mg} \mathrm{L}^{-1}\right)\end{array}$ & $10.31 \pm 6.89$ & $9.40-11.06$ & \\
\hline $\begin{array}{l}\text { Chloride } \\
\left(\mathrm{mg} \mathrm{L}^{-1}\right)\end{array}$ & $1275.59 \pm 51.21$ & $1203.5-1312.25$ & $200-300$ \\
\hline $\begin{array}{l}\text { Phosphate } \\
\left(\mathrm{mg} \mathrm{L}^{-1}\right)\end{array}$ & $6.89 \pm 0.19$ & $6.70-7.03$ & \\
\hline $\begin{array}{l}\text { Sulphate } \\
\left(\mathrm{mg} \mathrm{L}^{-1}\right)\end{array}$ & $11.60 \pm 0.78$ & $10.75-12.63$ & $<250$ \\
\hline Nitrate $\left(\mathrm{mg} \mathrm{L}^{-1}\right)$ & $0.01 \pm 0.00$ & $0.00-0.01$ & 50 \\
\hline $\begin{array}{l}\text { Bicarbonate } \\
\left(\mathrm{mg} \mathrm{L}^{-1}\right)\end{array}$ & $1349.40 \pm 185.30$ & $1095-1531$ & \\
\hline $\begin{array}{l}\text { Arsenic } \\
\left(\mathrm{mg} \mathrm{L}^{-1}\right)\end{array}$ & ND & & 0.01 \\
\hline $\begin{array}{l}\text { Calcium } \\
\left(\mathrm{mg} \mathrm{L}^{-1}\right)\end{array}$ & $6.0 \pm 0.06$ & $2.0-15.0$ & $100-200$ \\
\hline $\begin{array}{l}\text { Potassium } \\
\left(\mathrm{mg} \mathrm{L}^{-1}\right)\end{array}$ & $10.0 \pm 2.05$ & $7.0-20.0$ & \\
\hline $\begin{array}{l}\text { Sodium } \\
\left(\mathrm{mg} \mathrm{L}^{-1}\right)\end{array}$ & $28.0 \pm 1.08$ & $21.0-38.0$ & 200 \\
\hline $\begin{array}{l}\text { Magnesium } \\
\left(\mathrm{mg} \mathrm{L}^{-1}\right)\end{array}$ & $4.0 \pm 0.02$ & $2.0-7.0$ & 250 \\
\hline $\begin{array}{c}\text { Iron } \\
\left(\mathrm{mg} \mathrm{L}^{-1}\right)\end{array}$ & $1.50 \pm 0.08$ & $1.40-1.60$ & 0.30 \\
\hline $\begin{array}{l}\text { Manganese } \\
\left(\mathrm{mg} \mathrm{L}^{-1}\right)\end{array}$ & $0.17 \pm 0.09$ & $0.10-0.30$ & 0.40 \\
\hline $\begin{array}{l}\text { Cadmium } \\
\left(\mathrm{mg} \mathrm{L}^{-1}\right)\end{array}$ & ND & & 0.003 \\
\hline
\end{tabular}

SD- Standard Deviation, ND-Not Detected, BOD-Biological Oxygen Demand

\section{Discussions}

Water $\mathrm{pH}$ values of groundwater samples collected in Agbara and Igbesa were acidic while the $\mathrm{pH}$ of Lusada sample was slightly alkaline. Agbara and Igbesa water samples fell below the WHO limit for $\mathrm{pH}$ in drinking water given as 6.5 to 8.5 (WHO, 2008). The implication of the low $\mathrm{pH}$ may include corrosion, solubility of heavy metals and impartation of bitter and metallic taste in water (USEPA, 2007). However, the water hardness was very high in all the sampled groundwater, and might reduce the dissolution of metals (Adeyeye and Ayejuyo, 2002) against metal toxicity. Similarly, low $\mathrm{pH}$ in these boreholes may be attributed to dissociation of carbonic acid in the aquifer due to their unconfined nature (Zhou, 2006). Chemical contaminants from Agbara Industrial Estate seeping into groundwater might also have resulted into low water $\mathrm{pH}$. Similar low $\mathrm{pH}$ values have been observed by Efe et al. (2005) in groundwater samples from Niger-Delta of Nigeria.

Redox potential is a measure of a water system's capacity to either release or gain electrons in chemical reactions (Eaton et al., 1995). The essence of RP measurement in 
water is to evaluate corrosions of metals in drinking water. The range of RP in this study will not cause corrosion but may be considered in normal range of $350 \mathrm{mV}-390$ $\mathrm{mV}$ (EnviroEquip, 2007). Positive RP in the samples indicated that the boreholes are oxidizing with appreciably high dissolved oxygen.

Owen and Blair (1996) have defined Electrical conductivity as a measure of dissolved ions or salinity in water. EC values obtained in this study could be described as good according to Sadashivaiah, et al. (2008) classification of EC in water (Table 5). WHO desirable limit for EC in drinking water is $1000 \mu \mathrm{S} \mathrm{cm}^{-1}$. All the observed mean values of EC fell within this limit. High salinity in groundwater may be associated with alluvial aquifers (Geetha et al., 2008).

Table 5. Salinity Standard (Sadashivaiah, et al., 2008)

\begin{tabular}{c|c}
\hline $\mathbf{E C}\left(\boldsymbol{\mu} \mathbf{S ~ c m}^{-1}\right)$ & Class \\
\hline $100-250$ & Excellent \\
$250-750$ & Good \\
$750-2250$ & Doubtful \\
$>2250$ & Unsuitable
\end{tabular}

High BOD in groundwater is a signal of organic pollution. The extreme high values of BOD recorded across the borehole in the three communities indicated that the groundwater resources were polluted. Water with BOD greater than $4 \mathrm{mg} \mathrm{L}^{-1}$ is considered a rejectable source by Kothandaraman and Ewing (1969) as depicted in Table 6. Environmental Canada (1977) and (1979) has classified water BOD values greater than $10 \mathrm{mg} \mathrm{L}^{-1}$ as polluted. Elevated values of BOD in these groundwater samples might probably be from infilteration of leachates from nearby dumpsites and septic tanks into the groundwater resource. Adekunle et al. (2007) reported a high value of BOD (35.0 mg L $\left.\mathrm{m}^{-1}\right)$ in groundwater close to defecating sites in Igbora, Nigeria. Abnormal values of BOD in groundwater could harbour pathogenic organisms which may cause water-borne diseases.

Table 6. BOD Standard for Raw Water: (Source: Kothandaraman and Ewing, 1969)

\begin{tabular}{c|l}
\hline Average BOD value $\left(\mathbf{m g ~ L}^{-1}\right)$ & \multicolumn{1}{c}{ Class } \\
\hline $0.25-1.5$ & Excellent source \\
$1.5-2.5$ & Good source \\
$2.5-4.0$ & Porous source \\
Greater than 4.0 & Rejectable source
\end{tabular}

Sulphate and nitrate values were generally low in the groundwater samples with very slim possibility of initiating any health problems when the water is consumed. However, the mean values of phosphate in the groundwater was high, and could be attributed to weathering of underlain phosphate rocks in the aquifers and from other point sources. High phosphate values have been reported in groundwater near landfill site (Longe and Balogun, 2009). The greatest threats to groundwater quality and quantity include nutrient loading from agricultural fields, urban run-off, industrial effluents (and other contaminants that could infiltrate the groundwater systems), climate change, and high groundwater use (Danielopol et al., 2003).

Mean values of chloride in this study exceeded WHO recommended maximum limit of $250 \mathrm{mg} \mathrm{L}^{-1}$ in drinking water. High chloride and electrical conductivity in 
groundwater might be attributed to the intrusions of saline water from the coastal water (Department of National Health and Welfare (Canada), 1978). The studied areas fall under coastal plain Formation (Jones and Hockey, 1964). The chloride concentration of these study areas was very high with possible effect on health (Wesson, 1969) and impairment of water taste. Other environmental considerations of high chloride concentration are increases pitting corrosion of metal pipes, elevation of metals in drinking water and galvanic corrosion (Gregory, 1990).

Bicarbonate values of the groundwater samples are generally high, which may due to the underlain sedimentary rock. Groundwater samples in the study areas follow the geochemical trend in terms of abundance of ions as follows: Agbara $\left(\mathrm{HCO}_{3}{ }^{-}>\mathrm{Cl}^{-}>\right.$ $\mathrm{SO}_{4}{ }^{2-}>\mathrm{Na}^{+} / \mathrm{Ca}^{2+}>\mathrm{K}^{+}>\mathrm{NO}_{3}{ }^{-}$; Igbesa $\left(\mathrm{Cl}^{-}>\mathrm{HCO}_{3}{ }^{-}>\mathrm{Ca}^{2+}>\mathrm{Na}^{+}>\mathrm{SO}_{4}{ }^{2-}>\mathrm{K}^{+}>\mathrm{NO}_{3}{ }^{-}\right.$ ) and Lusada $\left(\mathrm{HCO}_{3}{ }^{-}>\mathrm{Cl}^{-}>\mathrm{Na}^{+}>\mathrm{SO}_{4}{ }^{2-}>\mathrm{Na}^{+}>\mathrm{K}^{+}>\mathrm{Ca}^{2+}>\mathrm{NO}_{3}{ }^{-}\right)$. The rock types of these aquifers were mainly bicarbonate and chloride types.

All the metals data collected from Agbara and Lusada groundwater samples except iron were low and met the permissible standards in drinking water (WHO, 2008). In Igbesa water samples, only the values of $\mathrm{Fe}$ and $\mathrm{Cd}$ were higher than the WHO permissible limits. Cadmium toxicity may include cancer (JECFA, 2000), hypertension, renal failure (Krajnc et al., 1987), proteinura and itai-itai disease (WHO, 2008; JECFA, 1989). Iron has no health effect on healthy individual as it is required by the body as essential trace metal (Finch, 1972). However, it could impart taste and offensive odour in water at concentration greater than $0.3 \mathrm{mg} \mathrm{L}^{-1}$. (Lemley et al., 1999). Iron and Manganese in the samples from Lusada were higher than WHO standard. Manganese has similar effects as iron in drinking water. Ayedun et al. (2011) and Gbadebo and Taiwo (2011) had previous reported high concentrations of Fe, $\mathrm{Mn}$ and $\mathrm{Cd}$ in boreholes sampled in Sango, which is about $10 \mathrm{~km}$ away from the study areas.

\section{Conclusion}

The geochemical compositions of the groundwater of the study areas showed that the water quality was poor in terms of chloride concentration and this would definitely affect the taste of the water. The higher values of iron, greater than WHO standard in the groundwater from the study areas could also affect the taste of the water. The presence of considerable value of cadmium in Igbesa groundwater samples is a major concern to public health. However, other parameters were within the permissible standard. In terms of abundance of ions, the predominant ions in the aquifers are: bicarbonate, chloride, sulphate, calcium, sodium, potassium while nitrate level was very low. Chloride removal from the groundwater samples in the study areas could be expensive since it cannot be done by ordinary filtration or boiling. However, the visible method of its removal could be achieved by reverse osmosis, deionization and distillation. This paper recommends proper and routine monitoring of groundwater resources in Agbara and environs. 


\section{REFERENCES}

[1] [Gregory, R. (1990): Galvanic corrosion of lead solder in copper pipework. - J. Institute of Water and Environmental Management 4(2):112-118.

[2] Adekunle, I.M., Adetunji, M.T., Gbadebo, A.M., Banjoko, O.B. (2007): Assessment of groundwater quality in a typical rural settlement in southwest, Nigeria. - International Journal of Environmental Public Health 4(4): 307-318.

[3] Ademoroti, C.M.O. (1996): Standard methods for water and effluents analysis. - Foludex Press Ltd., Ibadan. Pp.32-118.

[4] Adeyeye, E.I., Ayejuyo, O.O. (2002): Assessment of the physicochemical status of a textile industry's effluent and its environment. - Pakistan Journal of Scientific and Industrial Research 45: 10-16.

[5] APHA (1989): Standard Methods for the Examination of Water and Wastewater $\left(17^{\text {th }}\right.$ ed.). - American Public Health Association, American Water Works Association and Water Pollution Control Federation, Washington, DC.

[6] Danielopol, D., Griebler, C., Gunatilaka, A., Notenboom, J. (2003): Present state and future prospects for groundwater ecosystems. - Environmental Conservation 30: 104130.

[7] Department of National Health and Welfare (Canada) (1978): Guidelines for Canadian drinking water quality. - Supporting documentation, Ottawa, 1978.

[8] Eaton, A.D., Clesceri, L.S., Greenberg, A.E., eds. (1995): Standard Methods for the Examination of Water and Wastewater, $19^{\text {th }}$ edition, Washington, D.C. - American Public Health Association, American Water Works Association, and Water Environment Federation. Section 2580, Oxidation-Reduction Potential.

[9] Efe, S.I., Ogban, F.E, Horsfall, M. Jnr, Akporhonor, E.E. (2005): Seasonal Variations of Physico-chemical characteristics in water resources quality in western Niger Delta region, Nigeria. - Journal of Applied Science and Environmental Management 9(1): 191-195.

[10] EnviroEquip. (2007): www.enviroequip.com/quipnotes/ORP.htm :Accessed: 12/06/2010

[11] Environment Canada. (1977): Surface water quality in Canada - an overview. - Water Quality Branch, Inland Waters Directorate.

[12] Environment Canada. (1979): Analytical methods manual. - Inland water Directorate, Water Quality Branch, Ottawa, Canada, Part 1-5.

[13] FEPA (Federal Environmental Protection Agency). (1991): National Interim Guidelines and Standards for Environmental Pollution in Nigeria. - Federal Environmental Protection Agency. p. 54-58.

[14] Finch, C.A., Monsen, E.R. (1972): Iron nutrition and the fortification of food with iron. Journal of American Medical Association 219:1462-1465.

[15] Gbadebo, A.M., Taiwo, A.M. (2011): Geochemical Characterization of Phraetic Aquifers in Area of Sango, Southwestern, Nigeria. - World Applied Science Journal 12(6): 815821.

[16] Geetha, A., Palanisamy, P.N., Sivakumar, P., Ganesh, P.K., Sujatha, M. (2008): Assessment of Underground Water Contamination and Effect of Textile Effluents on Noyyal River Basin In and Around Tiruppur Town, Tamilnadu. EJ. - The Chemistry 5(4): 696-705.

[17] JECFA. (1989): Toxicological evaluation of certain food additives and contaminants. Geneva, World Health Organization, Joint FAO/WHO Expert Committee on Food Additives; Cambridge, Cambridge University Press, pp. 163-219 (WHO Food Additives Series No. 24).

[18] JECFA. (2000): Summary and conclusions of the fifty-fifth meeting. - Geneva, 6-15 June 2000. 
[19] Jones, H.A, Hockey, R.D. (1964): The geology of parts of Southwest Nigeria, Geological Survey of Nigeria, pp. 14-42.

[20] Kothandaraman, V., Ewing, B.B. (1969): A probabilistic analysis of dissolved oxygenbiochemical oxygen demand relationships in streams. - J. Water Pollut. Contr. Fed. Part 2, R73-R90.

[21] Krajnc, E.I., Van Gestel, C.A.M., Mulder, H.C.M. (1987): Integrated criteria document. Cadmium - Effects. Appendix. - Bilthoven, National Institute of Public Health and Environmental Protection (Report No. 758476004).

[22] Lemley, A., Schwartz, J.J., Wagenet, L. (1999): Iron and Manganese in Household Drinking Water. Water Treatment Notes. Fact Sheet no.6. - Cornell Cooperative Extension, New York State College of Human Ecology. Retrieved April 10, 2004, from http://www.human.cornell.edu/txa/extensionlwq/resources.cfm.

[23] Longe, E.O., Balogun, M.R. (2010): Groundwater quality assessment near a municipal landfill, Lagos, Nigeria. - Research Journal of Applied Science and Engineering Technology 2(1): 39-44.

[24] Orebiyi, E.O., Awomeso, J.A., Martins, O., Idowu, A.O., Oguntoke, O., Taiwo, A.M. (2010): Assessment of pollution hazards of shallow well water in Abeokuta and environs. - American Journal of Environmental Sciences 6(1): 50-56.

[25] Rahaman, M.A. (1976): Review of Basement complex in Nigeria: its petroleum geology, resources and potentials. - Whitemen, A.J. (ed.), Vol 1,. pp. 71-76.

[26] Sadashivaiah, C., Ramakrishnaiah, C.R., Ranganna, G. (2008): Hydrochemical analysis and evaluation of groundwater quality in Tumkur Taluk, Karnataka State, India. International Journal of Environmental Research and Public Health 5(3): 158-164.

[27] Taiwo, A.M. (2010): Environmental impact of poultry farm operations on Alakata Stream at Isolu in Abeokuta, Nigeria. - Unpublished Masters Thesis. Department of Environmental Management and Toxicology, University of Agriculture, Abeokuta. 108p.

[28] Taiwo, A.M., Adeogun, A.O., Olatunde, K.A., Adegbite, K.I. (2011): Analysis of groundwater quality of hand-dug wells in peri-urban area of Obantoko, Abeokuta, Nigeria for selected physic-chemical parameters. - The Pacific Journal of Science and Technology 12(1): 527-534.

[29] Todd, D.K. (1980): Groundwater Hydrology ( $2^{\text {nd }}$ Ed.). - John Wiley and sons. New York. $535 \mathrm{p}$.

[30] USEPA. (2007): Secondary drinking water standards. www.epa.gov/safewater/consumer/2ndstandards.htm (Accessed: 12/06/2010)

[31] Wesson, L.G. (1969): Physiology of the human kidney. - Grune and Stratton, New York, NY, $591 \mathrm{p}$.

[32] WHO. (2008): World Health Organization, Guidelines for drinking water quality, $3^{\text {rd }}$ Ed. Incorporating the first and second addenda. - Vol. 1 Recommendation, Geneva.

[33] Yusuf, K.A. (2007): Evaluation of groundwater quality characteristics in Lagos-City. Journal of Applied Sciences 7(13): 1780-1784.

[34] Zhou, X., Li, R., Zhang, H., Zhang, L. (2006): Characteristics of natural low pH groundwater in the coastal aquifers near Beihai, China. - Chinese Journal of Geochemistry 25(1): 228. 